UNTAG Law Review (ULREV)

Volume 1, Issue 1, May 2017, PP 78-88

ISSN 2549-4910 (online) \& ISSN 2579-5279 (print)

http://jurnal.untagsmg.ac.id/indeks.php/ulrev/indeks

www.fakhukum.untagsmg.ac.id

\title{
IMPLEMENTATION OF PRODUCT STANDARDIZATION POLICY SMALL AND MEDIUM INDUSTRY (IKM) IN WOOD PROCESSING RESULTS ${ }^{1}$
}

\author{
Wijaya, Sri Mulyani \\ Faculty of Law, Universitas 17 Agustus 1945 Semarang \\ Emiliana \\ Faculty of Economic, Universitas 17 Agustus 1945 Semarang
}

\begin{abstract}
The policy of the Minister of Trade which stipulates Ministerial Regulation No. 97 / M-DAG / PER / 12/2014 on the provisions on the export of forestry industry products implements the obligation to apply product standardization with SVLK (Timber Legality Verification System) to processed wood products from January 1, 2015. SVLK requirements for Small and Medium Enterprises (IKM), especially wood furniture and handicraft industries, are simplified in the form of self declaration as set forth in the document "Export Declaration." However, the Export Declaration Policy set by the government as an alternative for furniture business actors who do not have SVLK does not apply in European market and Australia. The results of research in Central Java Province found the furniture industry as a superior product, the number of SMEs that canceled its export contract causing the loss by stopping furniture exports even though this effort is done by the government in order to improve competitiveness.
\end{abstract}

Keywords : IKM Standardization Policy, Export Contract

\section{PROBLEM BACKGROUND}

In the business world, the company is where the production process and processing that will produce a product. According to Article 16 number 1 jo Article 17 letter $\mathrm{c}$ of Law Number 20 of 2008 regarding SMEs that the Government and Local Government encourage SMEs to apply standardization in production and processing process. SME's products in this case small and medium industries (SMEs) in order to compete in domestic market, ASEAN and international free market, especially on wood processing result must apply product standardization. As stipulated in the policy of the Minister of Trade, the Minister of Trade Decree No. 97 / MDAG/PER/12/2014 on the Export Regulation of Forestry Industry Products imposed the obligation to apply product standardization with SVLK (Timber Legality Verification System) to processed wood products from January 1,2015.

SVLK (Timber Legality Verification System) is an attempt to convince the market that the raw materials used are legal, but the indirect certification mechanism will make the price of raw materials more expensive than raw materials without certification, the increase in operating

1 Part of Competitive Grant Research, first year, 2016, Establishment of Product Standardization System of UMKM Based on Good Corporate Governance in Effort to Support Economic Development, No.kontrak :B.09/04.024/PRT-PHB/V/2016, Dipa Dikti The budget year 2016 
costs by itself makes the price of the product increases. SVLK ownership is not only for exporters, but must be owned by the whole network in the process (cutting, cutting / cutting, production, raw materials, finished goods), that is, exporters who already have SVLK still can not get V-legal if one of the chain Its supply has no legality'.

Based on the coordination meeting of three ministers (Trade, Environment, and Forestry and Industry) with the Heads of relevant offices throughout Indonesia and the Indonesian Furniture and Handicraft Association (AMKRI) on November 24, 2014, the agreement was obtained, firstly, SVLK will remain in effect on January 1, 2015, Second, for small and medium enterprises (SMEs) and Small and Medium Enterprises with registered status of registered Exporters of Forestry Industry Products, but not yet having SVLK can use export declaration ${ }^{3}$.

The Export Declaration (DE) is set by the government as an alternative for furniture business actors who do not have SVLK certificates, but this DE policy for small and medium industries does not apply in European and Australian markets. Five furniture industries in Central Java canceled their export contracts which caused losses by stopping furniture exports, even though this effort was made by the government in order to improve competitiveness ${ }^{4}$. This paper will examine the factors underlying the birth of SVLK enforcement policy on wood processing and the existence of export declaration in export contracts of wood processing products.

\section{RESEARCH METHODS}

This research falls into the realm of social-legal research, because the research is conducted not only on the juridical text alone, but also interpreting the text with social facts in people's lives. This is the case in the attempt to distort the rule of law within the framework of gaining understanding and interpretation of the juridical text that departs from the point of view of the researcher as well as the resource persons. In addition, this research is also a philosophical research (Yusriyadi, $2009:$ 12), because the research on the principles of law is an ideal element of the law. In this study, the law is interpreted not only as a juridical text (the formulation of articles of legislation), but is also interpreted as a moral-ethical document that constitutes the values of an abstract and subjective economic community activity.

\section{RESEARCH RESULTS AND DISCUSSION}

\section{SVLK Enforcement Policy on Wood Processing Results}

Understanding of policy according to Harold D. Lasswell and Abraham Kaplan is a program of achieving goals, values and practices that are directed (a projected program of goals, values and practices) ${ }^{5}$. Implementation of a policy of public interest is structured on the authority of policymakers. The policy assessment may include the content of the policy, the implementation of discretion and the impact of discretion. All three elements are crucial to the success or failure of an implementation ${ }^{6}$.

2 Bisnis Indonesia, 4 July 2016, p.3 in http://koran.bisnis.com

3 Ibid, hlm.2

4 Solahudin Ali, Executive Secretary of the Association of Indonesian Furniture and Handicraft Industries (ASMINDO) Regional Commissioner of Soloraya said many IKM claimed to be losing, because they had to stop their exports to Europe and Australia, Sucofindo in http:///www.sucofindo.co.id, 15 Januari 2015

5 Harold D. Lasswell dan Abraham Kaplan, Power and Society, New Haven: Yale University Press, 1970, hal. 71 in Sri Mulyani, Warehouse Receipt policies as Object Banking Credit Guarantee : Efforts to Support Economic Development in Indonesia, International Journal of Business, Economic and Law, Volume 7, E-ISSN 2289-1552, Desember 2015, p.76

6 M. Irfan Islamy, Prinsip-prinsip Perumusan Kebijaksanaan Negara, Bumi Aksara, cet VIII, 1997, Jakarta, 1997, hal. 20, in Sri Mulyani, ibid. 
The regulatory system of product standardization is spread in Law, Government Regulation and Ministerial Regulation. Related to the object of this research is the product of Small and Medium Industry (IKM) in the field of wood processing products (furniture), as set forth in the Minister of Trade Policy stipulating Ministerial Regulation No. 97 / M-DAG / PER / 12/2014 concerning Provisions on the Export of Industrial Products Forestry implements the obligation to apply product standardization with SVLK (Timber Legality Verification System) to processed wood products from January 1, 2015; Regulation of the Minister of Trade No. 25 / M-DAG / PER / 4/2016 on Amendment to Regulation of the Minister of Trade No. 89 / M-DAG / PER / 10/2015 on Provisions on Export of Forestry Industry Products; Regulation of the Minister of Environment and Forestry of the Republic of Indonesia Number: P.30 / Menhk / Sekjen / PHPL.3 / 3/2016 on Performance Assessment of Sustainable Production Forest Management and Verification of Timber Legality on Permit Holder, Right of Management or on Right Forest; Law Number 3 Year 2014 on Industry; Law No. 7/2014 on Trade; Government Regulation Number 102 Year 2000 on National Standardization; Regulation of the Minister of Environment and Forestry Number P.13 / MENLHK-II / 2015 on Business License for Forest Product Primary Industries.

In the context of the SVLK (Timber Legality Verification System) policy as stipulated in the Minister of Trade Policy stipulating Ministerial Regulation No. 97 / M-DAG / PER / 12/2014 on Provisions on Export of Forestry Industry Products imposed the obligation to apply product standardization with SVLK (Timber Legality Verification System ) To processed wood products starting January 1, 2015. SVLK enforcement policy is either a government initiative or commitment to combating illegal logging and promoting legal timber in Indonesia. The system aims to ensure that timber and wood products produced in Indonesia come from verifiable legal sources.

The SVLK policy philosophy is the acquisition of traceability of timber products, it is impossible for illegal timber to produce legal products, nor can a timber product be called legal, if the supply of raw materials is illegal. SVLK is implemented through a certification mechanism by an independent party (Timber Legality Verification Institution / LVLK) that has been accredited by the National Accreditation Committee ${ }^{7}$. SVLK serves to ensure that wood products and raw materials are obtained or derived from sources of origin and whose management meets the legality aspect. Timber is called legal, if the origin of wood, logging permits, systems and procedures for logging, transportation, processing, and trade or transfer may be proved to meet all the requirements. Certification is valid only 3 years and annually there is surveillance.

IKM in this regulation is Small and Medium Industry which owns ETPIK (Registered Exporters of Forestry Products), does not yet have S-LK (Timber Legality Certificate) with investment value up to 10 billion Rupiah outside land and building. Qualified SMEs will be included in the list of SMEs that may use export declarations pursuant to Decree of the Director General of Foreign Trade, Ministry of Commerce.

The idea of the introduction of SVLK enforcement policy provides a value of benefit, for the entire supply chain in the timber industry to earn income. For the government, besides getting taxes, also eradicate illegal logging. For the people of the world will the availability of clean air and avoid the threat of climate change and natural disasters (landslides, floods). Jeremy Bentham of the utilitarianist argues that a legislation should be able to provide the greatest

7 Interview with Head of Sub Division of Wood Processing Division, Disperindag of Central Java Province, dated June 2016 
happiness for most people. But the value of certainty and justice value has not touched the user of the policy. As Gustav Radbruch, who has made a great contribution to the existence of ideals (Idee des Rechts), is supported by the presence of three basic values (Grundwerten), namely justice (gerechtigkeit), benefits (Zweckmaeszigheit) and legal certainty (rechtsscherkeit).

In the concept of the welfare state, the State is responsible for presenting the welfare of its citizens as a social right of citizens, requiring the state to increase its competitiveness. In the face of increasingly fierce competition in the era of globalization required the readiness of the business world as one of the efforts to face the competition is necessary instrument in the arrangement of SVLK system. SVLK settings can be seen in the table below:

Table 1: SVLK settings

\begin{tabular}{|c|c|}
\hline Legal Basis of SVLK & $\begin{array}{l}\text { The policy of the Minister of Trade which } \\
\text { stipulates the Ministerial Regulation No. } 97 \\
\text { / M-DAG / PER / } 12 / 2014 \text { on the provisions } \\
\text { on the export of forestry industrial products } \\
\text { implements the obligation to apply product } \\
\text { standardization with SVLK (Timber } \\
\text { Legality Verification System) to processed } \\
\text { wood products }\end{array}$ \\
\hline $\begin{array}{l}\text { SVLK Implementation Guidelines } \\
\text { and Standards }\end{array}$ & $\begin{array}{l}\text { Perdirjen Bina Usaha Kehutanan No: P. } 8 \\
\text { VI-BPPHH / } 2012 \text { on Standards and } \\
\text { Guidelines on Assessment of Sustainable } \\
\text { Production Forest Managem ent } \\
\text { Performance (SFM) and Timber Legality } \\
\text { Verification(VLK). }\end{array}$ \\
\hline $\begin{array}{l}\text { Benefits obtained by the company } \\
\text { when obtaining a certificate of } \\
\text { timber legality }\end{array}$ & $\begin{array}{l}\text { - Saving time and expense for V-Legal } \\
\text { document issuance without being } \\
\text { required for inspection } \\
\text { - Increase buyer's trust in The legality of } \\
\text { the products being exported } \\
\text { - A form of compliance with government } \\
\text { regulations } \\
\text { - Can use V-Legal mark on the product. }\end{array}$ \\
\hline Stages of obtaining SVLK & $\begin{array}{l}\text { - Application application to LVLK } \\
\text { - Docs Review } \\
\text { - Set Schedule } \\
\text { - Publication of Audit Plan on Kemenhut } \\
\text { website, } \\
\text { - LVLK village / kelurahan where industry } \\
\text { is located or mass media } \\
\text { - Audit Field } \\
\text { - Decision-making decision } \\
\text { - Publication of published certificates. }\end{array}$ \\
\hline
\end{tabular}

Source: Global Forest \& Trade Network 
Wijaya, Sri Mulyani, Emiliana : Implementation Of Product Standardization Policy Small ...

The benefits of SVLK for business is ${ }^{8}$ :

1. Businesses will get value added (premium price) on the sale of certified products.

2. Increasing the breadth of the market for the sale of certified products;

3. Securing market access to States that have established regulations on procurement of wood products procurement only from certified sources;

4. For the industry will increase the image in the eyes of buyers for producing products derived from sustainably managed forests;

5. Industries can self-endorsement when they get certificate of timber legality.

\section{Existence of Export Declaration in Export Contract of Wood Processing Result}

In business transactions / import-export contracts, the role of the contract is increasingly important, as it deals with other parties abroad. In addition to contracting differently in degree of difficulty, foreigners also have different social values and practices as well as different legal systems. These differences can lead to misunderstandings. Therefore, the business that conducts the business of import-export business must really understand the requirements. In the import-export contract there is a Sales's Contract is an agreement from exporters and importers to trade goods in accordance with mutually agreed terms, whereby the parties are bound to implement all agreed obligations. Any party who breaks the promise will be penalized by paying compensation to the injured party.

In Indonesian national law, in order for a contract / agreement to be binding on the parties, it must meet the requirements of the validity of the agreement as regulated in Article 1320 of the Civil Code. In the preparation of business contracts between business actors related to the implementation of the contents of the contract, must also consider the habits applicable in international trade. In Indonesian national law recognizes this customary practice which can be seen in Article 1339 of the Civil Code that: a covenant is not only binding on things expressly stated therein, but also to anything that by nature of the treaty, necessitated by propriety, custom or law.

Habits in international trade related to export contracts of wood products where buyers require the existence of SVLK documents (Timber Legality Verification System) that must be owned for furniture exporters. For furniture exporters who do not have SVLK documents, have only export declaration documents, then export contracts of wood products are canceled, despite the policy of export declaration document on government initiation. The export declaration itself is an independent declaration made by IKM, containing a statement that the delivered product meets the timber legality requirements specified by the international market. Declaration is written on a special blank, for further perpetrators of the IKM signature on the stamp Rp6000. This is a manifestation of the filler's accountability of the validity of his product. IKM must also be equipped with ETPIK (Registered Exporters of Forestry Industry Production), and IKM does not have V-Legal yet. "V-Legal is a sign of conformity to the verification of timber legality affixed on timber and wood products or packaging stating that wood or wood products have fulfilled Standards for sustainable production forest management or timber legality verification standards. This export declaration is specifically used for furniture entrepreneurs who do not have SVLK due to limited turn over. The aid in the

8 Sucofindo, Certification of Wood Legality in http://www.sucofindo.co.id, hlm.2 
Wijaya, Sri Mulyani, Emiliana : Implementation Of Product Standardization Policy Small ...

form of export declaration will be given for one year ie from 1 January to 31 December $2015^{9}$. In business activities, the provisions that govern it are not necessarily directly followed by IKM (Small and Medium Industry), but sometimes there are difficulties of small and medium furniture crafters to export their products because they do not have a Verification and Legality System of Wood (SVLK) assisted by the government by issuing the Export Declaration. The export declaration document is a government commitment aimed at Small Medium Enterprises (IKM) that exports, but does not yet have SVLK. IKM furniture can use export declaration with some provisions among them the IKM must already have TDI (Industrial Register Number) or IUI (Industrial Business License) which include investment value of not more than Rp 10 billion.

Guidelines for Export Declaration Publishing

\begin{tabular}{|c|c|}
\hline A. Scope & $\begin{array}{l}\text { Issuance of the Export Declaration for IKM } \\
\text { ETPIK Owners Furniture subject to Regulation } \\
\text { of the Minister of Trade No. } 64 \text { / M-DAG / } \\
12 / 2012 \text { which does not have Certificate of } \\
\text { Timber Legality (S-LK) in executing exports. }\end{array}$ \\
\hline B. References & $\begin{array}{l}\text { 1. Regulation of the Minister of Forestry } \\
\text { Number P.43 / Menhut-II / } 2014 \text { as } \\
\text { amended the latest by Regulation of the } \\
\text { Minister of Environment and Forestry } \\
\text { Number P.95 / Menhut-II / } 2014 \text { on the } \\
\text { Assessment of Sustainable Production } \\
\text { Forest Management Performance and } \\
\text { Verification of Timber Legality on License } \\
\text { Holder or On Right Forest. } \\
\text { 2. Regulation of the Minister of Trade No. } 64 \\
\text { / M-DAG / } 12 / 2012 \text { concerning Provisions } \\
\text { on the Export of Forestry Industry } \\
\text { Products, together with the amendments. }\end{array}$ \\
\hline $\begin{array}{l}\text { C. Issuance of Export } \\
\text { Declaration }\end{array}$ & $\begin{array}{l}\text { 1. Preparation of the issuance of the Export } \\
\text { Declaration } \\
\text { a. ETPIK who can issue an Export } \\
\text { Declaration is the IKM owner of } \\
\text { ETPIK determined by the Director } \\
\text { General of Foreign Trade on behalf of } \\
\text { the Minister of Trade based on } \\
\text { recommendation or input from the } \\
\text { Director General of Small and Medium } \\
\text { Industry of the Ministry of Industry. }\end{array}$ \\
\hline
\end{tabular}

9 Nurlaila Nur Muhammad, Director of Export of Agriculture and Forestry Production Directorate General of Foreign Trade Ministry of Trade, Socialization of SVLK in Semarang, January 7, 2015 in http://bisnis.liputan6.com/read/2157703/kemendag-keluarkan-deklarasi-ekspor-bagi-pelaku-usaha-ikmmebel, Uploaded on October 17, 2016 
b. ETPIK which shall issue the Export Declaration shall file the application of Access Right to the Director General c.q Director.

c. Access Rights as referred to in point $b$ are obtained by filling in the registration sheet and the statement of the applicant provided electronically from http://silk.dephut.go.id. The registration sheet is then printed in company letterhead for signing and stamped on the seal Rp. 6,000, -. The scanned copy of the applicant's registration sheet is sent by electronic mail to the address of deklarasiekspor@dephut.go.id.

d. Access Rights referred to in points b and c is only valid for the issuance of the Export Declaration and is valid until December 31, 2015.

2. Export Declaration Issuance Mechanism

a. The issuance of the Export Declaration is done by ETPIK IKM Furniture independently by filling out the Export Declaration document located at http://silk.dephut.go.id.

b. Charging done:

1) Electronically after obtaining the Right to issue the issuance of the Export Declaration; or

2) Manually (handwritten) using a printed Export Declaration document (or blank copyed form), completed with the signature of the leader (or signature of ETPIK officer authorized by the owner of ETPIK) and affixed with the IKM ETPIK stamp of the Furniture. Manual replenishment is done in case ETPIK Furniture does not have access right to export Electronic Document issuance.

c. In case the filling is done manually as referred to in point b.2), copies (copies) of the Export Declaration document are submitted to the Ministry of Environment and Forestry cq. LIU / SILK at the Directorate of Forest Product Processing and Marketing.

d. Export Declaration is printed as a customs document by IKM Owner of ETPIK Furniture. 
D. General Requirements of Export Declaration
1. Export Declaration in paper and / or electronic form.

2. Filling the Export Declaration using the Indonesian language, all in capital letters by filling in all parts (tamper proof) in such a way as to make it impossible to fill other than by ETPIK IKM Furniture and there shall be no smears, piercings or alterations.

3. The Guide to filling the Export Declaration is as well as the Export Declaration Charging Guide.

4. In case of issuance manually, the Export Declaration shall be signed by the ETPIK leader / officer authorized by the owner of ETPIK and affixed with IKM ETPIK stamp of furniture.

5. In the case of electronic access rights of issuance, the name of the ETPIK leadership / officer as referred to in point 4 along with IKM ETPIK signature and stamp specimen is submitted to the Director General c.q Director electronically (e-mail) or by mail delivery.

6. In the case of Electronic Export Declaration issued, LIU may provide information on the list of officers who signed the Export Declaration along with specimen of officer's signature and company seal to the Directorate General of Customs and Excise of the Ministry of Finance.

7. In case of incomplete Export Declaration, the Export Declaration may be accompanied by an attachment.

8. Export Declaration is only used for single shipment.

9. In the case of Electronic Export Declaration issued, Electronic Export Declaration shall be sent ETPIK IKM Furniture to SILK Online to be forwarded to INATRADE system at Ministry of Trade and Indonesian customs authority through Indonesian National Single Window (INSW) system.

10. ETPIK IKM Furniture submits PEB copy of the previous month to LIU no later than the 10 th of the ensuing month electronically or by mail. 


\begin{tabular}{|c|} 
D. General Requirements \\
of Export Declaration \\
\hline
\end{tabular} \mid

11. In the case of Electronic Export Declaration issued, the LIU System shall lock access to the issuance of the Export Declaration for ETPIK IKM Furniture that has not submitted PEB copy after 30 (thirty) days of Export Declaration issued.

12 ETPIK IKM Furniture documents and maintains all records of the Export Declaration for at least 1 (one) year.

1. Export Declaration in paper and / or electronic form.

2. Filling the Export Declaration using the Indonesian language, all in capital letters by filling in all parts (tamper proof) in such a way as to make it impossible to fill other than by ETPIK IKM Furniture and there shall be no smears, piercings or alterations.

3. The Guide to filling the Export Declaration is as well as the Export Declaration Charging Guide.

4. In case of issuance manually, the Export Declaration shall be signed by the ETPIK leader / officer authorized by the owner of ETPIK and affixed with IKM ETPIK stamp of furniture.

5. In the case of electronic access rights of issuance, the name of the ETPIK leadership / officer as referred to in point 4 along with IKM ETPIK signature and stamp specimen is submitted to the Director General c.q Director electronically (e-mail) or by mail delivery.

6. In the case of Electronic Export Declaration issued, LIU may provide information on the list of officers who signed the Export Declaration along with specimen of officer's signature and company seal to the Directorate General of Customs and Excise of the Ministry of Finance.

7. In case of incomplete Export Declaration, the Export Declaration may be accompanied by an attachment.

8. Export Declaration is only used for single shipment. 
9. In the case of Electronic Export Declaration issued, Electronic Export Declaration shall be sent ETPIK IKM Furniture to SILK Online to be forwarded to INATRADE system at Ministry of Trade and Indonesian customs authority through Indonesian National Single Window (INSW) system.

10. ETPIK IKM Furniture submits PEB copy of the previous month to LIU no later than the 10th of the ensuing month electronically or by mail.

11. In the case of Electronic Export Declaration issued, the LIU System shall lock access to the issuance of the Export Declaration for ETPIK IKM Furniture that has not submitted PEB copy after 30 (thirty) days of Export Declaration issued.

12. ETPIK IKM Furniture documents and maintains all records of the Export Declaration for at least 1 (one) year.

Source: Regulation of Director General of Forest Business Development

In response to the existence of export contracts on timber processing where the ownership of Export Declaration documents is the reason for the abandonment of the export contract of furniture delivery, indicates that the lack / tolerance in international business relations. Therefore the need to establish communication in international business transactions to avoid misunderstandings which are of course very harmful for furniture exporters.

\section{CLOSING}

\section{Conclusion}

The implementation of the standardization policy of IKM products on wood processing products with the ownership of SVLK (Timber Legality Verification System) provides the value of benefit, for the entire chain of suppliers in the timber industry to earn income both government and society, although the value of certainty and justice value has not touched Users of the policy.

The international business transactions contained in the export contract especially on the wood processing result require the SVLK document (Timber Legality Verification System). With the ownership of SVLK documents, Indonesian wood products are more accepted by European markets. The objective of the SVLK-based legal verification policy on timber processing results is to guarantee certain specifications or to convince the international market that the raw materials used are halal. 
Wijaya, Sri Mulyani, Emiliana : Implementation Of Product Standardization Policy Small ...

\section{Recommendation}

Basing on the conclusion of research result and discussion of policy study of IKM product standardization on wood processing result (furniture), hence can put forward some thoughts as input (recommendation), that is :

1. The need for socialization in the small and medium industries (SMEs) of processed wood products on the importance of SVLK ownership through the SVLK Clinic (Legality Verification System of Timber) both at the municipal and district level, so that IKM gets its benefits.

2. There is a need for an Implementing Regulation concerning Product Standard for IKM on Consistent Processing Result of wood (furniture) and not spread in various regulations either at ministerial level or government level.

\section{REFERENCES}

Harold D. Lasswell dan Abraham Kaplan, Power and Society, New Haven: Yale University Press, 1970

M. Irfan Islamy, Prinsip-prinsip Perumusan Kebijaksanaan Negara, Bumi Aksara, cet VIII, 1997, Jakarta, 1997

Nurlaila Nur Muhammad, Direktur Ekspor Produksi Pertanian dan Kehutanan Direktorat Jenderal Perdagangan Luar Negeri Kementerian Perdagangan, Sosialisasi SVLK di Semarang, 7 Januari 2015 dalam http://bisnis.liputan6.com/read/2157703/kemendagkeluarkan-deklarasi-ekspor-bagi-pelaku-usaha-ikm-mebel, Uploaded on October 17, 2016

Sri Mulyani, Warehouse Receipt policies as Object Banking Credit Guarantee : Efforts to Support Economic Development in Indonesia, International Journal of Business, Economic and Law, Volume 7, E-ISSN 2289-1552, Desember 2015

Sucofindo, Sertifikasi Legalitas Kayu in http://www.sucofindo.co.id

Yusriadi, 2009, Tebaran Pemikiran Kritis Hukum dan Masyarakat, Surya Pena Gemilang, Malang, 